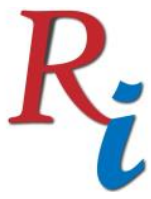

Asia Proceedings of Social Sciences

(APSS)

www.readersinsight.net/APSS

\title{
HOW ENGAGING ARE YOU? EMPIRICAL EVIDENCE FROM MALAYSIAN RESEARCH UNIVERSITIES
}

\section{Mohamad Rahimi Mohamad Rosman*}

Faculty of Information Management

Universiti Teknologi MARA Kelantan

Malaysia

rahimimr@uitm.edu.my

\section{Mohd Nasir Ismail}

Faculty of Information Management

Universiti Teknologi MARA Kelantan

Malaysia

Nasir733@uitm.edu.my

\section{Mohamad Noorman Masrek}

Faculty of Information Management

Universiti Teknologi MARA Puncak Perdana

Malaysia

mnoorman@uitm.edu.my

*Corresponding author’s Email: rahimimr@uitm.edu.my

Peer-review under responsibility of 4th Asia International Multidisciplinary Conference 2020 Scientific Committee http://connectingasia.org/scientific-committee/ (C) 2020 Published by Readers Insight Publisher, lat 306 Savoy Residencia, Block 3 F11/1,44000 Islamabad. Pakistan, editor@readersinsight.net This is an open access article under the CC BY-NC-ND license (http://creativecommons.org/licenses/by-nc-nd/4.0/). 


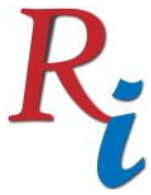

\section{Asia Proceedings of Social Sciences (APSS) \\ www.readersinsight.net/APSS}

\section{A b s t r a c t}

Digital library engagement is the extensive use of digital library features and services. Contrary to the traditional concept of usage, DL engagement evaluates the use of an information system based on multiple dimensions; affective, cognitive, and behavioural. Presently, there is scarce evidence and research on the level of DL engagement. Lack of such evidence caused underutilization of DL resources. Therefore, our research intends to determine the degree of DL engagement among postgraduate students. A quantitative study was conducted; an instrument was distributed to postgraduate students in the context of Malaysian universities, focusing on research universities. 492 responses were recorded and descriptively analyses using statistical software. Next, the data were evaluated using independent sample t-test for two conditions, analysis of variance (ANOVA) for more than two conditions, and frequency analysis to identify significance difference and mean distribution of data among the participating universities. Results show that respondent's age and research domain showed a significant effect on DL engagement, while gender, study mode, level of study, semester, and the university did not show any significant effect on DL engagement.

\section{Rese a r ch H i g h I igh t s}

Based on the findings, it can be concluded that the current degree of DL engagement among postgraduate students at Malaysian research universities is very good with mean score of 5.0020 .

There is no significance different between DL engagement in relation to gender, study mode, and level of study.

There is a significant effect of respondent's research domain and age on DL engagement.

\section{Research Objectives}

The study aims to investigate the current degree of DL engagement among postgraduate students in Malaysian research universities. Similarly, the study also investigates the significant difference in the distribution of means within several demographic factors such as age, gender, semester, mode of study, level of study, and research domain.

\section{Methodology}

A quantitative study was conducted to investigate the current level of DL engagement among postgraduate students in Malaysian research universities. An instrument was developed by adopting and adapting to previous studies of Masrek and Gaskin (2016), Kiran and Diljit (2012), Masrek and Samadi (2017), and O'Brien and Toms (2010). The instrument was pretested, expert evaluations, and pilot test before actual data collection. Data collection took 


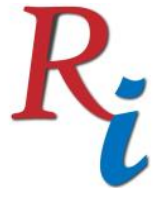

\section{Asia Proceedings of Social Sciences (APSS) \\ www.readersinsight.net/APSS}

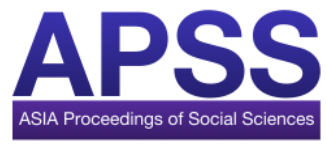

4 weeks in November 2019. The population of the respondents was selected based on convenience sampling method. A total of 493 responses were received, however, one response was excluded due to empty dataset.

\section{Results}

The findings of the study were interpret based on independent sample t-test for two conditions, frequency analysis, and one-way analysis of variance (ANOVA) for more than two conditions. We utilize the statistical package, Statistical Package for Social Science (SPSS) version 24 for the data analysis. The mean score for the factors underlying the cocenept of DL engagement are as follows: focus attention (4.363), felt involvement (5.1748), aesthethic (5.1408), and novelty (5.3293). The result of independent sample t-test are as follows: male (mean $=5.0250$, std. dev. $=1.02174)$ and female (mean=4.9882, std. dev. $=1.04529)$; conditions; $\mathrm{t}(490)=0.382, \mathrm{p}=$ 0.703 , fulltime $($ mean $=4.9781$, std. dev. $=1.03852$ ) and part-time (mean=5.0913, std. dev. $=1.02468)$; conditions; $\mathrm{t}(490)=-0.990, \mathrm{p}=0.322$, and doctorate $($ mean $=5.0036$, std. dev. $=$ 1.06923) and master (mean=5.0007, std. dev. =1.00772); conditions; $\mathrm{t}(490)=-0.094, \mathrm{p}=$ 0.925 . On the other hand, the ANOVA results are as follows: age $\rightarrow$ DL Engagement $[F(4,487)$ $=2.801, \mathrm{p}=0.025]$, semester $\rightarrow$ DL Engagement $[\mathrm{F}(7,484)=0.560, \mathrm{p}=0.789]$, research domain $\rightarrow$ DL engagement $[\mathrm{F}(6,485)=3.196, \mathrm{p}=0.004]$, and university $\rightarrow$ DL Engagement $[\mathrm{F}(4,487)=0.582, \mathrm{p}=0.676]$.

\section{Findings}

The findings of the study are as follows. First, it can be concluded that the current level of DL engagement among postgraduate students at Malaysian research universities is very good with a mean score of 5.0020. Second, there is no significant difference between DL engagement concerning gender, study mode, and level of study. Third, there is a significant effect of the respondent's research domain and age on DL engagement. Fourth, there is no significant effect of semester and universities on DL engagement.

\section{Acknowledgement}

We would like to thank the domain experts, administrators, and postgraduate students at the selected universities who were involved in this research project. Without their passionate participation and input, the completion of the study could not have been successfully conducted.

\section{References}

Kiran, Kumar, and S Diljit. 2012. "Modeling web-based library service quality." Library \& Information Science Research 34 (3):184-196. 




\section{Asia Proceedings of Social Sciences (APSS) \\ www.readersinsight.net/APSS}

Masrek, Mohamad Noorman, and James Eric Gaskin. 2016. "Assessing users satisfaction with web digital library: the case of Universiti Teknologi MARA." The International Journal of Information and Learning Technology 33 (1):36-56.

Masrek, Mohamad Noorman, and Ismail Samadi. 2017. "User engagement in academic web digital library." International Journal of Civil Engineering and Technology 8 (9):789-799.

O'Brien, Heather L., and Elaine G. Toms. 2010. "The development and evaluation of a survey to measure user engagement." Journal of the Association for Information Science and Technology 61 (1):50-69.

Author's Biography

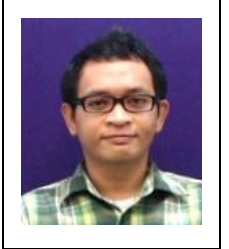

Mohamad Rahimi Mohamad Rosman is a senior lecturer and PhD candidate at the Department of Information System Management, Faculty of Information Management, Universiti Teknologi MARA Kelantan Branch, MALAYSIA. His research interest includes information system management, system development methodologies, and digital library engagement.

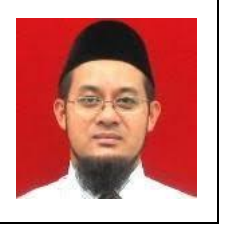

Mohd Nasir Ismail is an Associate Professor at the Department of Information System Management, Faculty of Information Management, Universiti Teknologi MARA Kelantan Branch, MALAYSIA. His research interest includes information system management, instructional design, and knowledge management. E-mail: nasir733@uitm.edu.my.

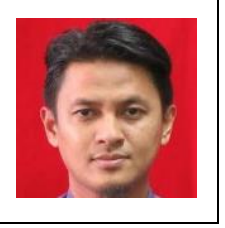

Mohamad Noorman Masrek is an Associate Professor at the Department of Information System Management, Faculty of Information Management, Universiti Teknologi MARA Shah Alam, MALAYSIA. His research interest includes information system development, system development methodologies, Intranet and Internet technologies. E-mail: mnoorman@uitm.edu.my 